\title{
Bionics IN ARCHITECTURE
}

\author{
Viktória Sugár ${ }^{1}$, Péter Leczovics², András Horkai ${ }^{1}$ \\ ${ }^{1}$ Institute of Architecture, Szent István University, Budapest, Hungary \\ Sugar.Viktoria@ybl.szie.hu \\ ${ }^{2}$ Institute of Civil Engineering, Szent István University, Budapest, Hungary \\ Leczovics.Peter@ybl.szie.hu
}

\begin{abstract}
The adaptation of the forms and phenomena of nature is not a recent concept. Observation of natural mechanisms has been a primary source of innovation since prehistoric ages, which can be perceived through the history of architecture. Currently, this idea is coming to the front again through sustainable architecture and adaptive design.

Investigating natural innovations and the clear-outness of evolution during the $20^{\text {th }}$ century led to the creation of a separate scientific discipline, Bionics.

Architecture and Bionics are strongly related to each other, since the act of building is as old as the human civilization - moreover its first formal and structural source was obviously the surrounding environment. Present paper discusses the definition of Bionics and its connection with the architecture.
\end{abstract}

Keywords: bionics, biomimicry, architecture, adaptive design, sustainability

\section{BIONICS}

\subsection{Bionics as a term}

According to the Hungarian Etymological Dictionary of Foreign Words, Bionics means: scientific discipline researching the mechanism and functions of animal organisms, from the perspective of technical usability [1].

Other sources define it as a discipline surveying natural forms (from macro to nano structures), and natural selection (which converted to engineering term means literally optimalization) evaluating the results for adaptation into other fields. In literature the terms Biomimicry or Biomimetics are also used to describe this interdisciplinary topic [2,3].

The name is originated from the Greek 'bios' (nature, life) and the English 'technics' words [4].

The above names are applied internationally to distinguish between diverse fields: Biomimicry or Biomimetics are used in engineering, Bionics spread in medical lingo in Anglo-Saxon region, however in German speaking countries Bionics is used for the overall discipline. 


\subsection{Bionics in Engineering}

Table 1 introduces the connection between engineering goals and Bionics, showing that in either micro and macro sized fields the results Bionics are able to help aiming for sustainability, green design, optimized structures and smart, adaptive buildings.

\begin{tabular}{|c|l|l|}
\hline Level & Natural example & Engineering goals \\
\hline \multirow{4}{*}{ Macro } & Forms and aesthetics & Forming and structure design aesthetics \\
\cline { 2 - 3 } & Structure and mechanics & High performance load bearing structures \\
\cline { 2 - 3 } & Material characteristics & Power source efficiency and adaptation \\
\hline \multirow{3}{*}{ Micro } & Function and mechanism & Multifunctional components \\
\cline { 2 - 3 } & Energy usage and source & Environmental friendly methods and sustainability \\
\cline { 2 - 3 } & Intelligent and responsive systems & Self-control and self-healing \\
\hline
\end{tabular}

Table 1. Connection between Bionics and Engineering goals [5]

\section{BIONICS IN ARCHITECTURE}

\subsection{Vernacular Architecture}

In the early stages of architecture since prehistoric ages, our ancestors started to build temporary, later permanent houses. Primary goal was protection against dangers of environment, like weather and wild animals. The most ancient architectural solutions can be still found in multiple parts of the world, for example the architecture of aboriginals in Africa (Figure 1,2).
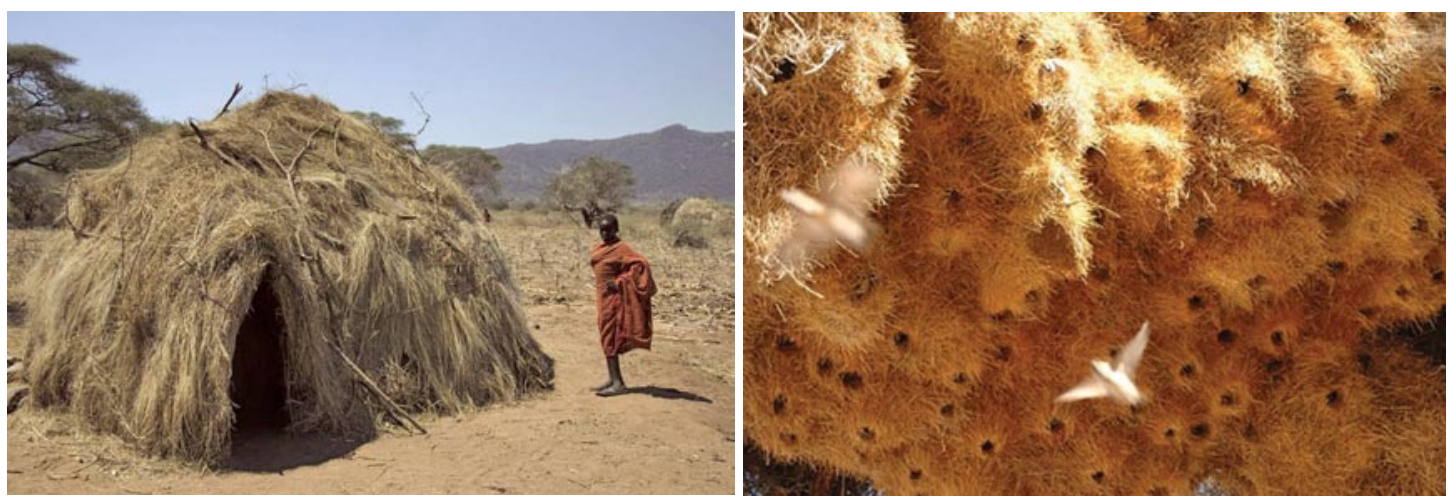

Figure 1. Hadza buildings in Africa and weaverbird nest [6,7] 

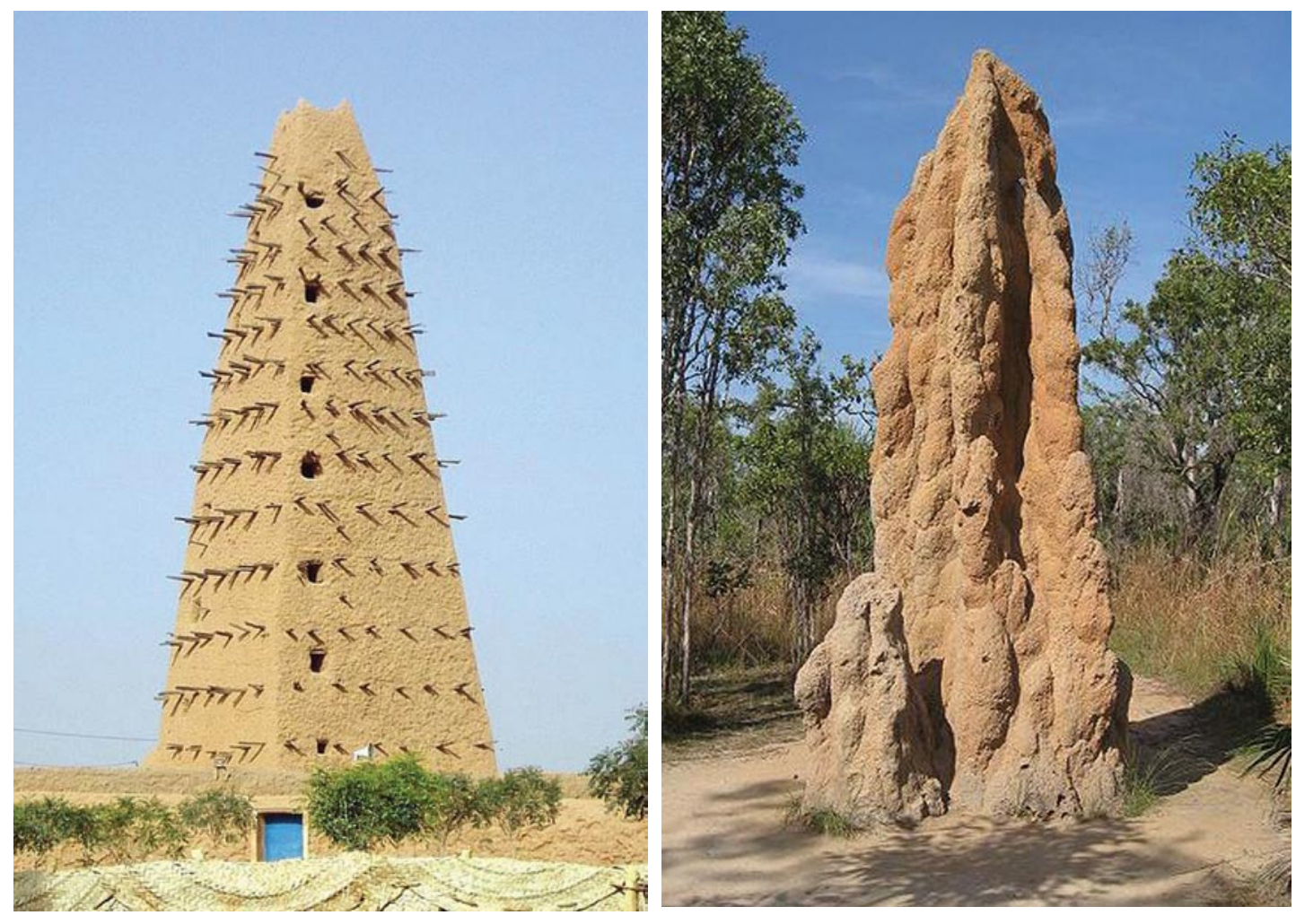

Figure 2. African minaret and termite mound $[8,9]$

In addition to adapting the form, the building materials used are also connected to the environment - rural architecture still uses materials which can be found in the immediate vicinity (Figure 3, 4).
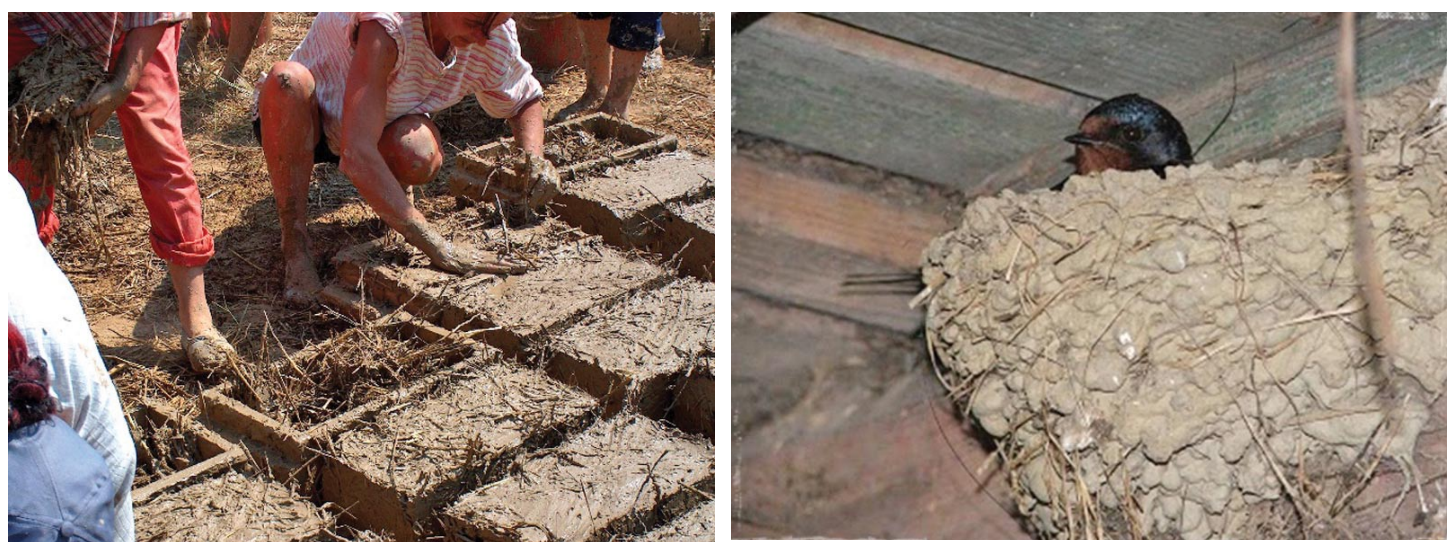

Figure 3. Handmade adobe and dove nest, Hungary $[10,11]$ 
Construction related Bionics thus appears in vernacular architecture, where the structure and the material are either inspired by nature.
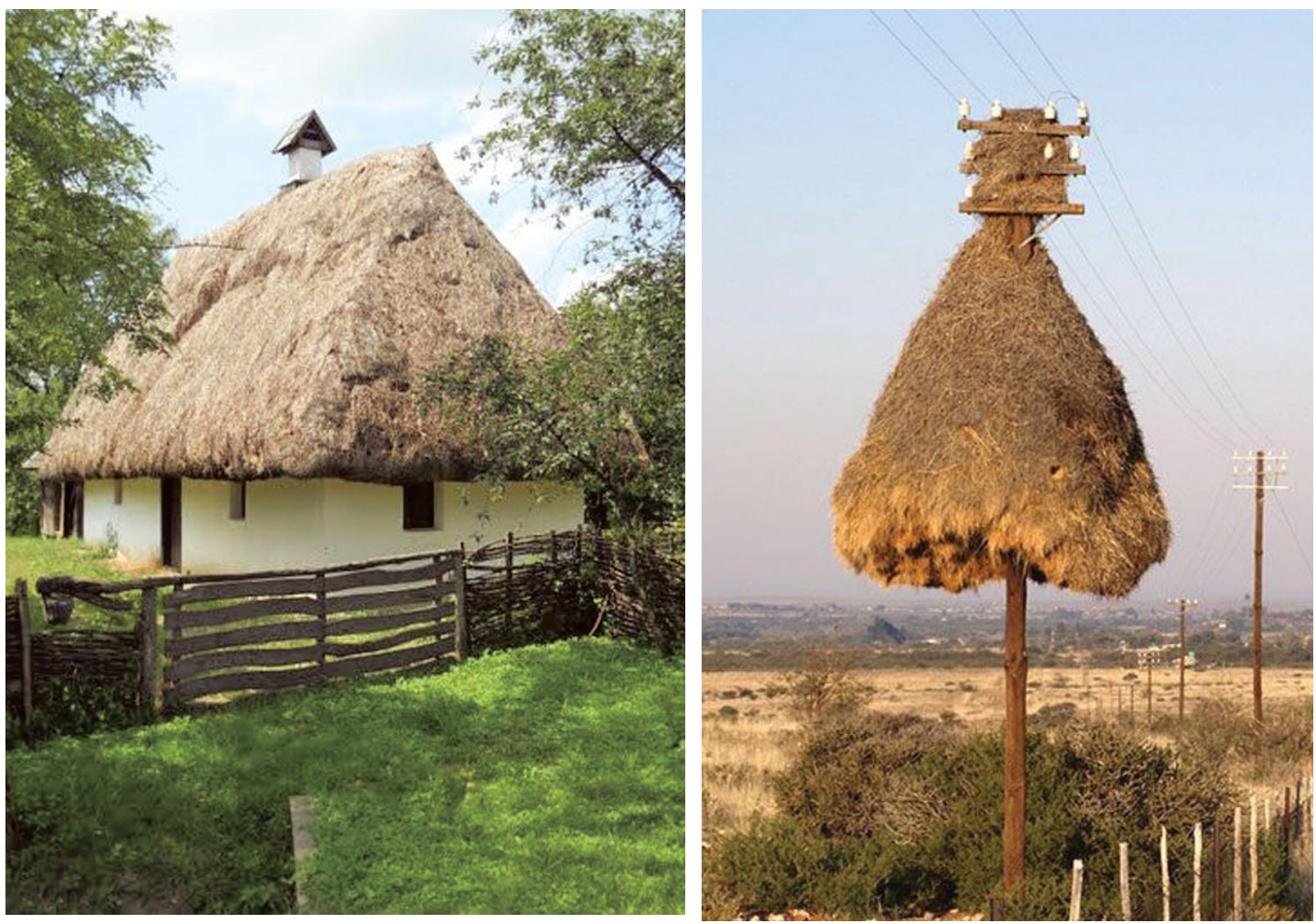

Figure 4. Tached roof in Hungary and weaver bird nest, Hungary $[12,13]$

In addition to individual buildings and materials, the structure of a settlement can also show signs of Structural Bionics. Mesa Verde, one of the communities of the Anasazi Indians has similarities with the Sand Martin birds' nests, which evolved due to defence reasons (Figure 5).

The above mentioned examples are mainly adapting macro-level Bionics (Table 1), using the form and the structure, and materials of the natural source.
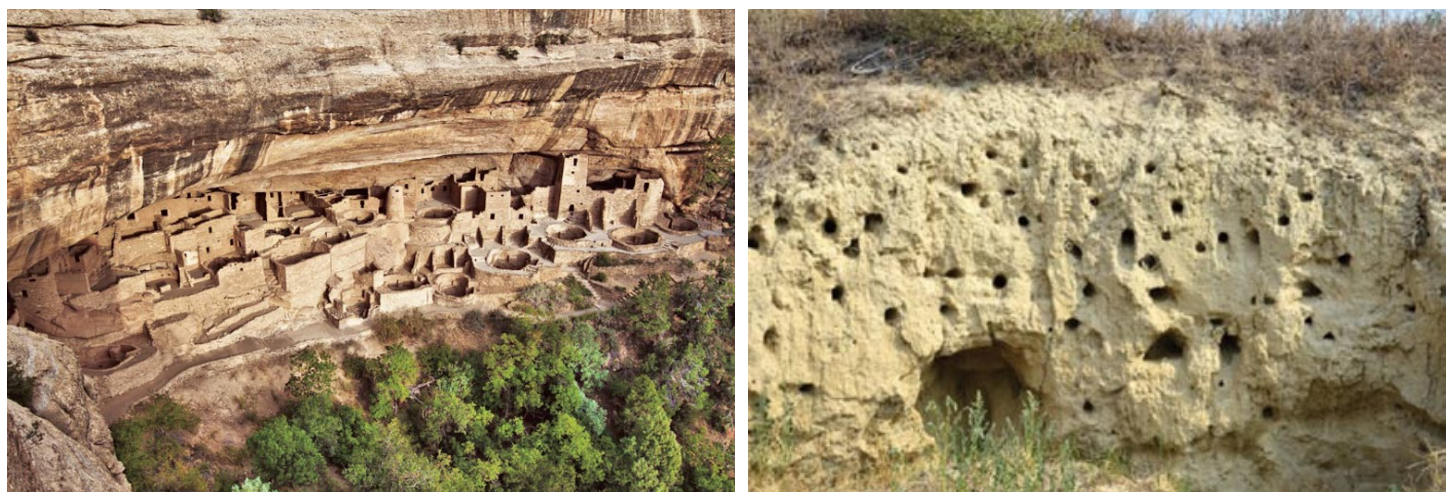

Figure 5. Mesa Verde and Sand Martin nests [14, 15] 


\subsection{Bionics in History of Architecture}

Natural inspiration appeared in many forms on buildings of the past. The following are but a few examples:

Construction Bionics can be observed on large stone structures such as Egyptian hypostyle halls (Figure 7):

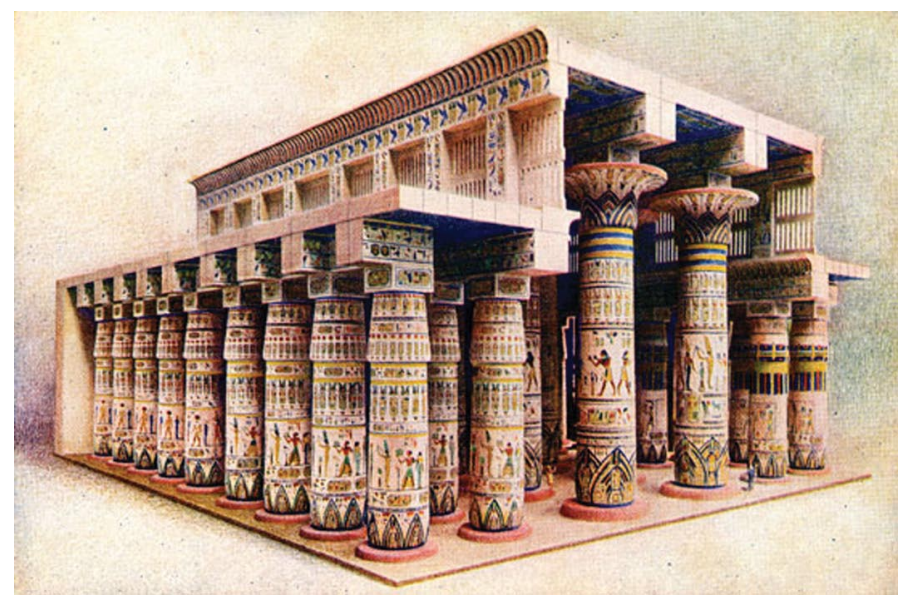

Figure 7. Sectional view of the Great Hypostyle Hall of Karnak with floral and bud column capitals [17]

One of the characteristic Egyptian structure is the column-beam stone structure. In the Great Hypostyle Hall of Karnak - built in the $13^{\text {th }}$ century BC -, columns show an interesting sign of Bionics: the base of the columns are narrower, which cannot be caused by structural considerations, since more stability would be provided by wider size. It is however an imprint of a more ancient construction method, adapted from the time when Egyptians had used papyrus plant piles.

It is worth to observe that the above Hall more deeply (Figure 7). It has a spatial structure later called "Basilica", where the nave is higher than the aisle, thus high windows on its wall provide lighting to the space. The columns lighted by the windows have open floral capitals, while the columns situated in darker parts of the aisle have bud columns - which is a clear reference to the life and growth provided by the Sun, thus adapting the micro and macro of Bionics levels also (Table 1).

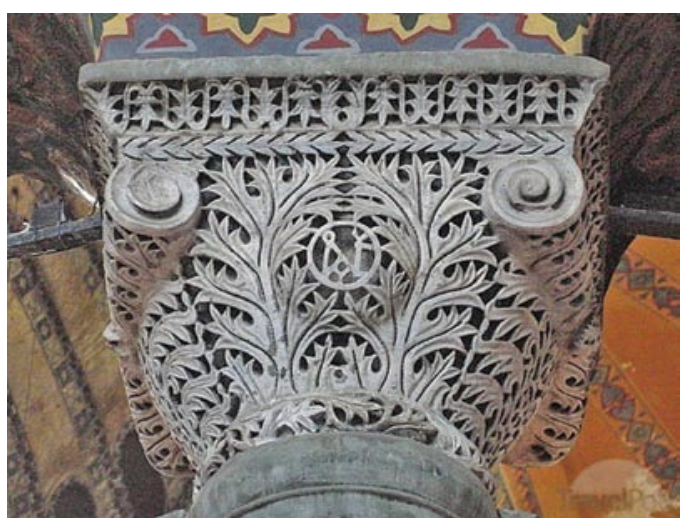

Figure 6. Byzantine column capital [16] 
Ornament is ever present during the history of architecture. While observing buildings built in different architectural styles, the surface decoration is the most notable part, on which natural analogies can be detected (Figure 6), for example in case of Byzantine architecture, where floral patterns were used to cover the plain structures.

Gothic architecture should also be mentioned concerning structural analogies. By its forms and frame construction, the builders have been stretching the boundaries of stone, their main building material. The style brought an entirely new set of architectural solutions. Through time, the structures have become increasingly skeletal, reaching to the limits of the material - thus some towers and cathedrals collapsed meanwhile construction. As a beautiful example of a filigree structure, the gothic fan vault should be mentioned, which is a reminiscent of a shellfish or palm leaf (Figure 8), adapting the natural phenomena on macro-level, structurewise.
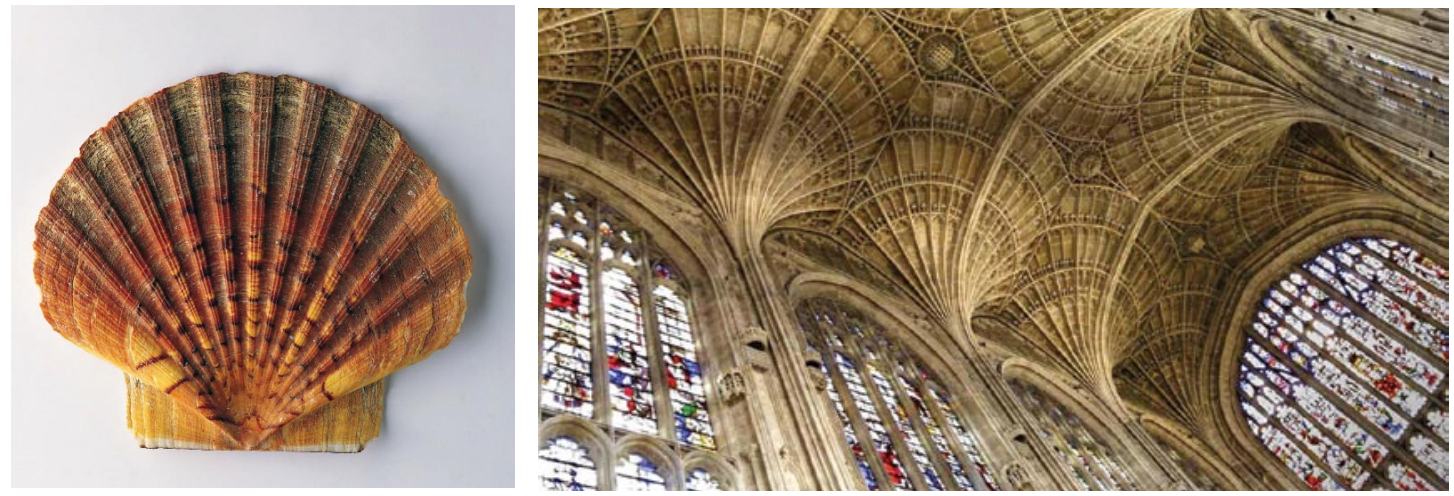

Figure 8 . Structure of a shell and a gothic fan vault $[17,18]$

An outstanding and innovative style, which separates itself from the previous antique and medieval traditions, is the Art Nouveau. In Hungary the style is referred as Secession - a distinctive style still well-liked by people. With its colourful floral ornaments Secession buildings are appealing and distinctive.

A famous designer of the Art Nouveau in Hungary was Ödön Lechner, whose building, the Museum of Applied Arts, is one of the most famous pieces of the style (Figure 9).

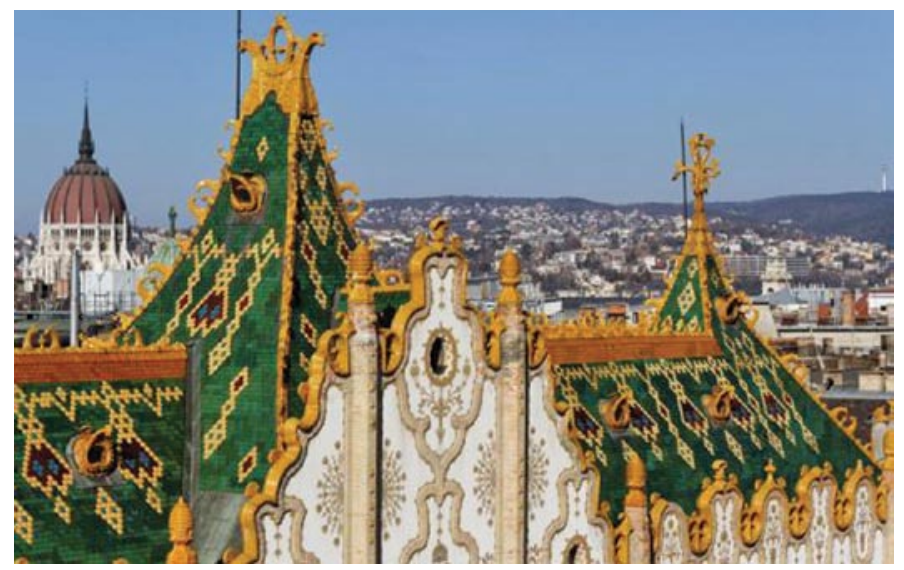

Figure 9. Secession style on the Museum of Applied Arts [24] 
The Hungarian Secession however mainly used the floral and animal analogies as ornaments, and did not reach the level of mimicking nature as did Gaudí's masterpieces - a real example of Structural Bionics, already appearing in the beginning of the $20^{\text {th }}$ century.

The Catalan architect Antoni Gaudí created an entirely individual, signature style also referred as Art Nouveau, although the level of his mimicry contains not only the ornaments as a surface, but building structures also, using Bionics as a complex adaptation source [19].

Gaudí realized that natural forms are able to provide more than decoration. Natural structures are not only aesthetically pleasing but in every way optimized functional units. His pillars refer to human bones or foliage (Figure 10), allowing to minimize the built-in material [20].
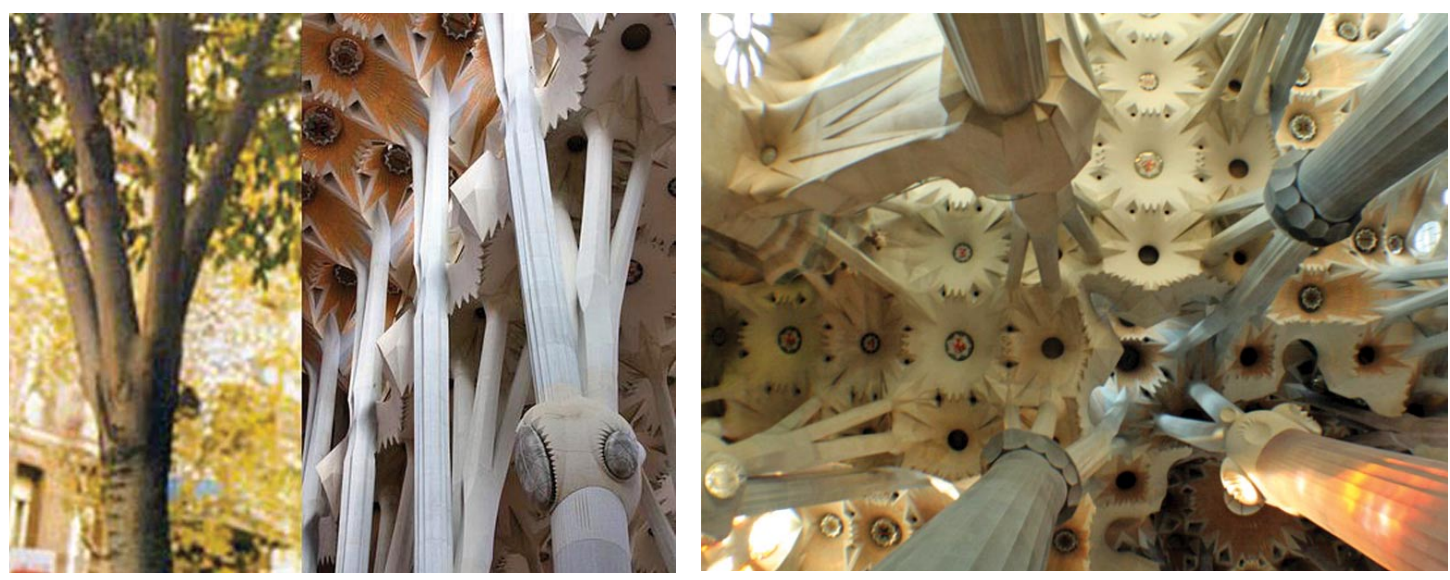

Figure 10. Structures in Gaudí's Sagrada Familia and tree branches [25, 26]

\subsection{Bionics in Contemporary Architecture}

Presently, by using software based computer modelling and structural design, wide range of new possibilities have been opened.

In case of Santiago Calatrava's buildings the first that comes in mind to people familiar with his works is the strongly suggestive biomorphic forming [21]. His architectural forms use human or animal skeleton analogies, demonstrating the aesthetic appeals of construction- and structural bionics .
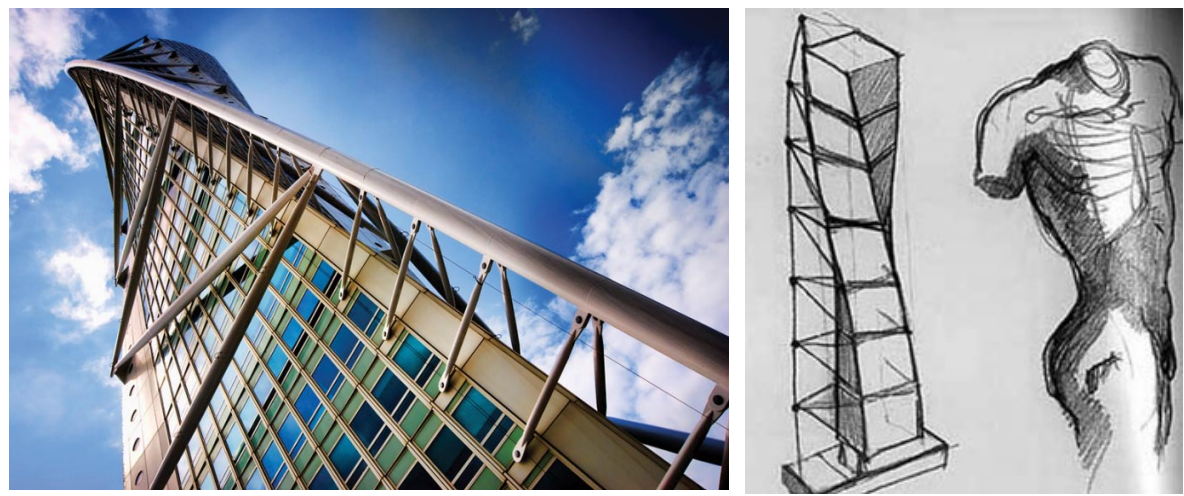

Figure 11. Calatrava's twisting skyscraper in Malmö [27, 28] 
The architects' first skyscraper named the "Turning Torso" was erected in Malmö, Sweden. As the name suggests, the original inspiration for forming which was a twisting human body. The 54-storey building twisting 90 degrees, offering full panoramic view (Figure 11) [22].

The Lisbon station is also a wood-analogy, although built almost a hundred years after Gaudí (Figure 12).

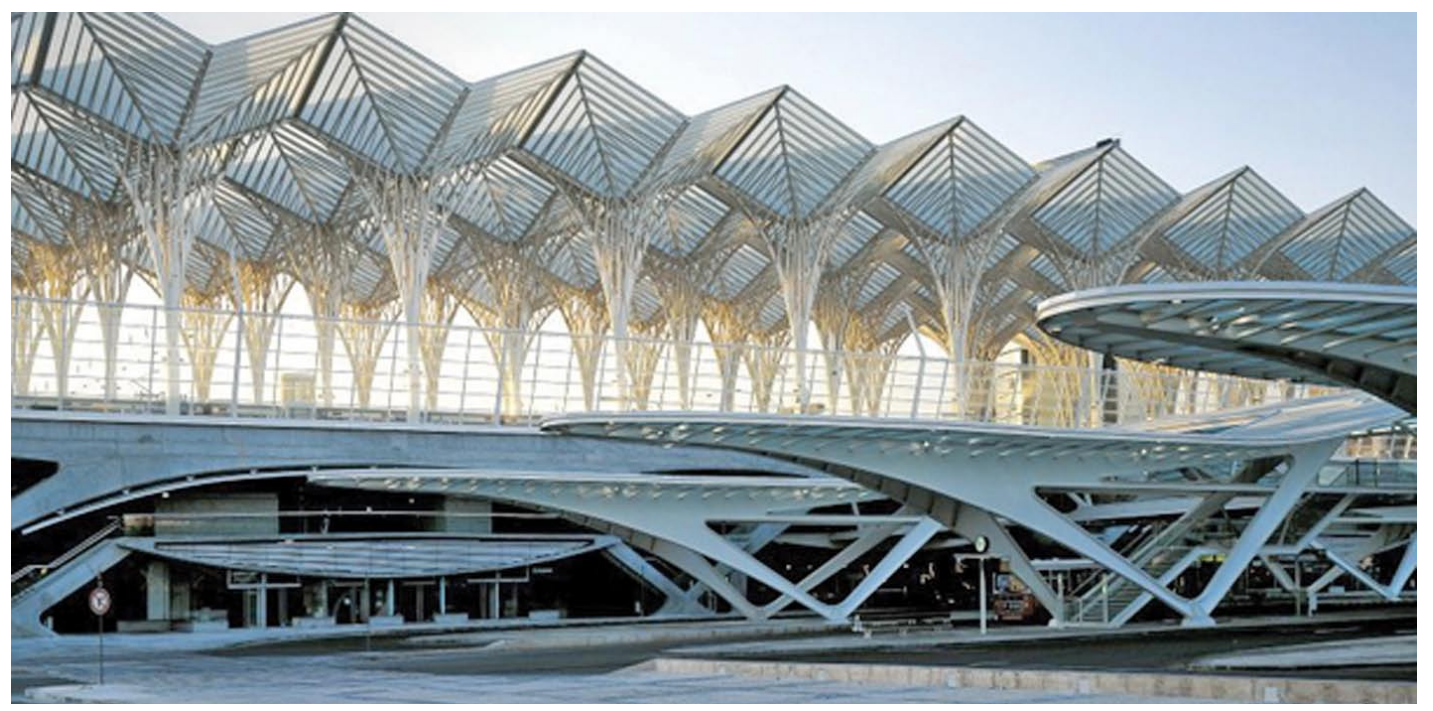

Figure 12. Calatrava’s Lisbon station [29]

Within the human analogies Calatrava's Planetarium in Spain is outstanding, a landmark formed from a sketch of an eyeball (Figure 13).
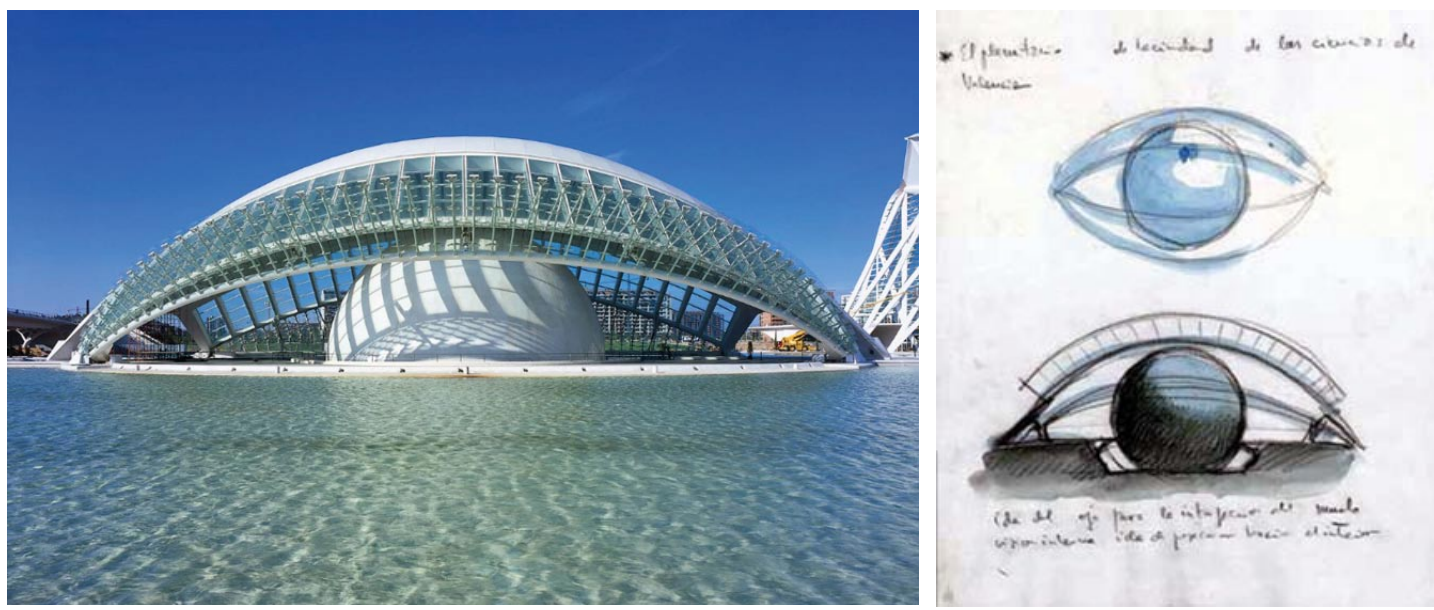

Figure 13. Calatrava's Planetarium in Spain $[30,31]$

Calatrava brought a unique, radically innovative shaping in his structures inspired by natural forms. The buildings erected during his 30 years of work -including 40 bridges and 10 stations -, are all iconic landmarks, however his investors occasionally experience some inconveniences: the buildings usually far exceed the planned budget [32]. 
The internationally renowned Hungarian architect Imre Makovecz often struggled with similar problems. Buildings of his design are admired nationwide (some even worldwide), however cost and structural problems are also been frequent in his case.

The Hungarian Organic Architecture as a style is labelled, and usually associated with him, however only half-correctly. Although signs of organic architecture can be spotted, his buildings are more formalist, more closely related to esoteric symbolism. The natural analogies are used mostly as ornaments or appear as symbolic but not vital additions.

Among his earlier works, the Funeral home of Farkasrét (built in 1977) is remarkable. The ceiling is a reminiscent of a human chest, implying an interesting relation between the form and the function (Figure 14).

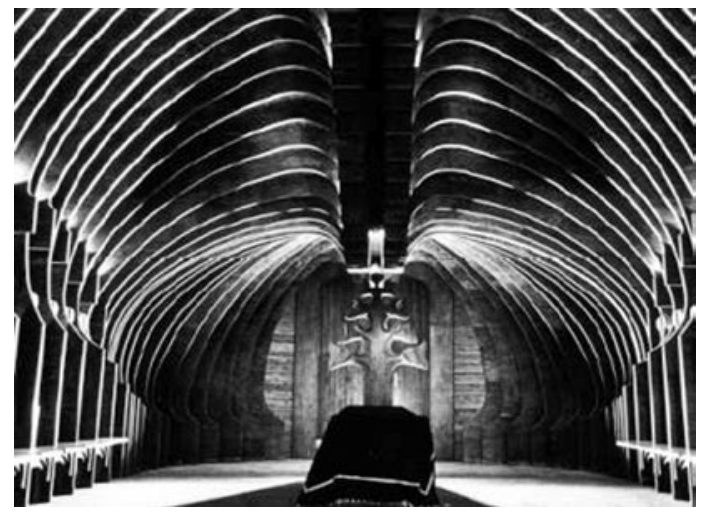

Figure 14. Funeral home of Farkasrét [33]

In case of Makovecz's later buildings symbolism and formalism are even more emphasised. Among his larger scale buildings, the Pázmány Péter University (1995) of Piliscsaba should be mentioned, where the natural analogies are used alongside the universal symbols, however the latter is more articulated (Figure 15).

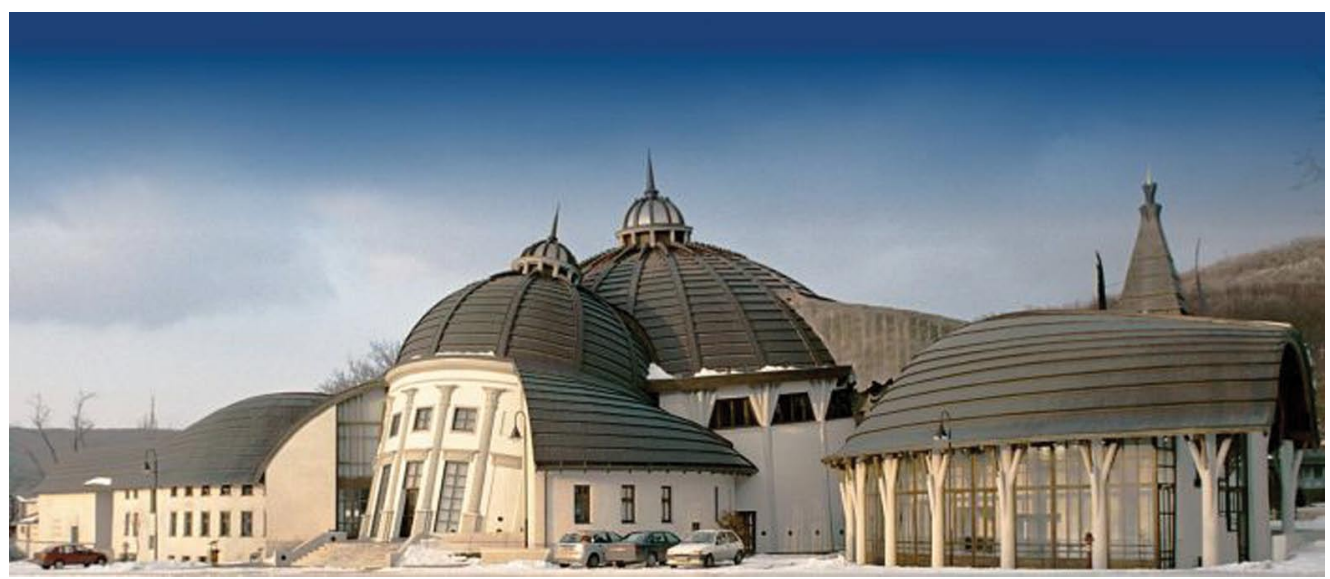

Figure 15. Funeral home of Farkasrét [34]

One of Makovecz's last works is the Újjászületés Chapel in Devecser, which has a unique entrance - a bold suggestion to womanhood (Figure 16). The wings located on the sides of the tower are also analogies, but only ornaments. 


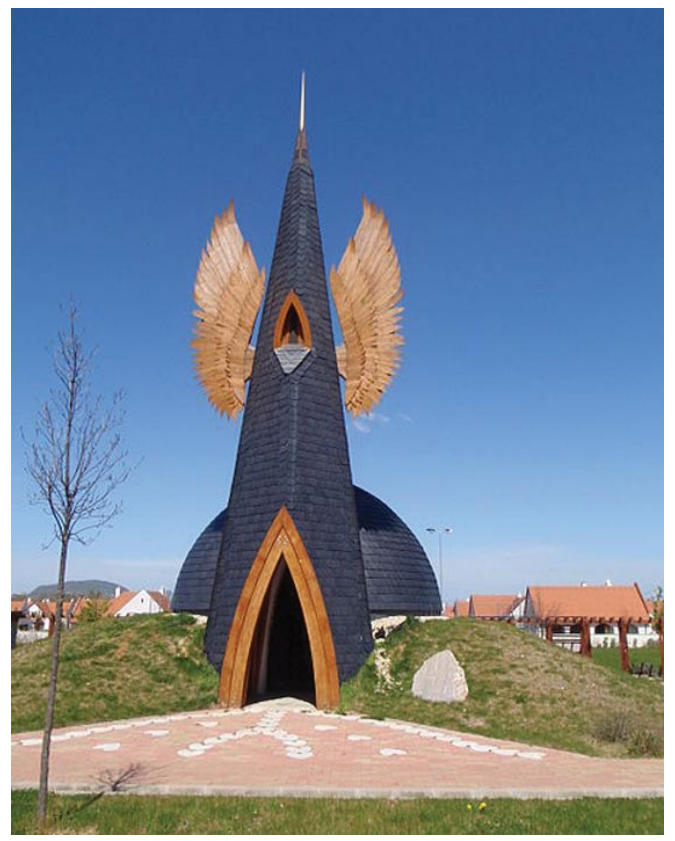

Figure 16. Újjászületés Chapel in Devecser [35]

In case of contemporary architecture, analysing bionics does not necessary means surveying buildings, or houses in the literal sense: public space compositions and other uncommon installations are also part of the topic. One of these, not yet implemented, although remarkable idea is the so called "TREEPOD", which is a tree-shaped device, mimicking the mechanism of a real tree. Similar the source, it can produce oxygen from the carbon-dioxide content of the air, behaving as an air cleaner. Its branches serve as shading to the pavement underneath, and the solar photovoltaic panels installed on the branches create electricity. The electricity is used for supplying the air cleaning device hidden into the structure. Moreover, the structure will be made of recycled PET bottles, making it more environmental-friendly [36].

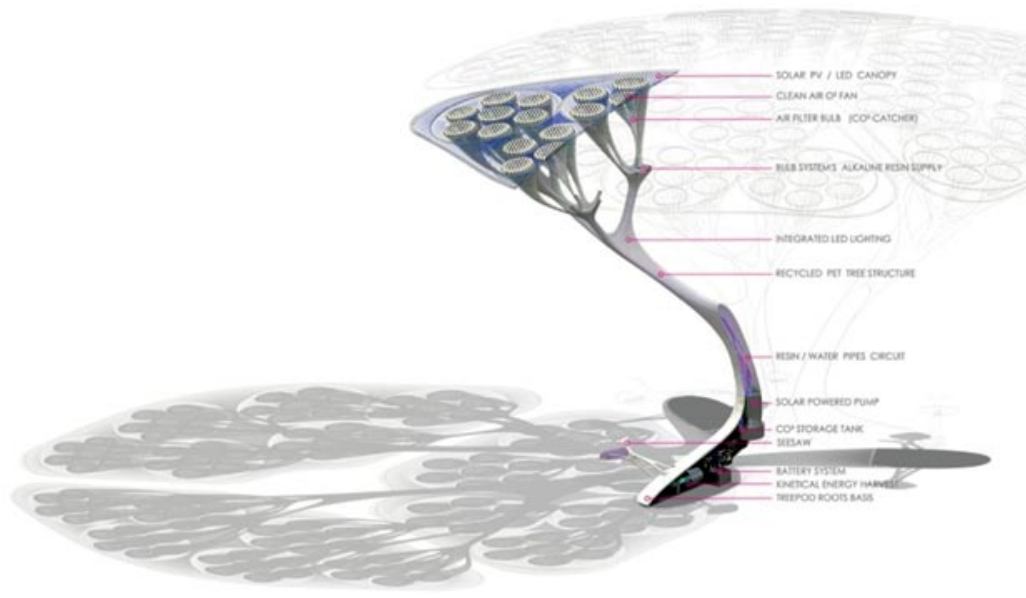

Figure 17. TREEPOD [30] 


\section{CONCLUSION}

Present paper is a shorter review of the extensive topic of Bionics in Architecture. The abovementioned buildings and structures are but a selection, the complete list of buildings and descriptions associated with biomimicry is beyond of the boundaries of the present study.

The examples show that Bionics and Architecture are closely related to each other, since the act of building is as old as human civilization - which obviously use the surrounding natural phenomena as its primary inspiration.

The vernacular architecture, also known as folk architecture is still keeping several millennia's building tradition alive, using natural forms and materials.

Through the history of architecture every style has taken inspiration from nature. In parallel with its progress, architecture moved away from nature, however recently starting to realize once more the great achievements of evolution.

With the advancement of materials science not only revolutionary shaping solutions, but modern materials are available, aiming towards cost- and material-saving, high performance structures.

Smart systems, as mimicry of a living ecosystem or organisation offers intelligent surveillance systems, responsive buildings and even the capability to synchronize whole district energetics.

It can be also concluded, that in ancient architecture, macro-level Bionics can be observed, by mimicking the form and structure of Nature. However, as the material science field and engineering evolves, the micro-level Bionics is more and more capable of using the natural phenomena as a source, creating smart and responsive systems mirroring the perfectly optimized natural systems.

The threat of global warming also pushes mankind towards sustainable and environmentally friendly solutions. By using contemporary computer modelling new routes are opening up for adapting complex solutions of nature. In this context however, designers and stakeholders also need a change of approach, to be able to use the methods of bionics more widely. At the same time there must be more emphasis on this under-represented topic in university education.

The development of architecture is ongoing, new solutions show up day-by-day. Architecture has always been slower in applying the most recent innovations, however at the same time, recent design proposals show that contemporary and future architecture requires the innovations of Bionics, in order to create sustainable buildings and cities.

\section{REFERENCES}

[1] TótfaLusi I., Idegenszó-Tár Idegen szavak értelmező és etimológiai szótára, Budapest, Tinta Könyvkiadó, 2004, ISBN 9637094927

[2] Benyus J. M., Biomimicry: Innovation Inspired by Nature. New York, Harper Perennial, 2002, 978-0060533229

[3] Gates P., Nature Got There First: Inventions Inspired By Nature, Kingfisher, London, 2010, 978-1554534678

[4] http://www.wisegeek.com/what-is-biomimicry.html

[5] Nan H., Gonglian D., Peng F., Value Of Bionic Research For Engineering Design Of Civil Structures: International Bionic Engineering Conference, 2011

[6] https://s-media-cache-ak0.pinimg.com/736x/57/35/1c/57351c7df040be83a89c534b7c313d43.jpg

[7] https://c2.staticflickr.com/2/1144/1342613894_a512b3a9c2.jpg

[8] http://borostyan.net/files/2011/08/termeszv\%C3\%A1r.jpg

[9] http://freevst.x10.mx/sahara/air/agadez/Agadez\%2017.jpg

[10] https://upload.wikimedia.org/wikipedia/commons/2/2a/RomaniaDanubeDelta_MakingMaterialForCOnstructing0002jpg 
[11] http://s6.images.www.tvn.hu/2010/08/06/15/40/www.tvn.hu_ab541846c1eec2432ad4c276432c814c.jpg

[12] http://www.szatmarifesztival.hu/szatmarcseke/telkep/tajhazj.jpg

[13] http://galeria.nlcafe.hu/files/752/075/000/75752/75752_625245_1000x700.jpg

[14] https://upload.wikimedia.org/wikipedia/commons/thumb/4/4f/Mesaverde_cliffpalace_20030914.752.jpg/250pxMesaverde_cliffpalace_20030914.752.jpg

[15] http://www.magyarszo.com/oldimages/57aa724e10e1b8b7775fc30da26e204a-telep.jpg

[16] http://images.travelpod.com/tw_slides/ta00/d82/c2a/top-of-a-column-inside-hagia-sophia-istanbul.jpg

[17] http://www.ancientegyptianfacts.com/Ancient-Egyptian-Columns-2.jpeg

[18] http://www.iwallfinder.com/time-memory/the-first-series-of-conch-shells-30054.jpg

[19] ZARI M. P., An architectural love of the living: Bio-inspired design in the pursuit of ecological regeneration and psychological wellbeing. Sustainable Development and Planning IV. WIT Press, Southampton, United Kingdom., 2009, pp. 293-302.

[20] ZARI M. P., Bio-inspired architectural design to adapt to climate change. Proceedings of the 2008 World Sustainable Building Conference, in by Foliente, G. et al (Eds), pp. 1-8. SB08

[21] NACHTIGALL, W., Bionik- Grundlagen und Beispiele für Ingenieure und Naturwissenschaftler, Springer, 1998, 978-3540-43660-7

[22] NACHTIGALL W., POHL G., Bau-Bionik, Natur - Analogien - Technik. Springer-Verlag Berlin Heidelberg, Berlin, 2013, 978-3-540-88995-3

[23] http://cache.wallpaperdownloader.com/bing/img/KingsCollegeChapel_20130310.jpg

[24] http://images.postr.hu/uploads/blogs/13646/188405/post_188405_20141120005920.jpg?full=1

[25] http://www.thethirdray.com/sculpture/our-relationships-to-nature-gaudis-architecture/

[26] http://2.bp.blogspot.com/-V0ys4V0vvxU/TcgghXx77BI/AAAAAAAAACQ/1tbU-G8WS9A/s1600/

Captura+de+pantalla+2011-05-09+a+las+19.10.54.png

[27] https://c1.staticflickr.com/3/2465/3947478336_4f361fd596_b.jpg

[28] http://www.arcspace.com/CropUp/-/media/20253/4torso.jpg

[29] http://imgs.abduzeedo.com/files/archi/calatrava/orient.jpg

[30] http://www.idesignarch.com/wp-content/uploads/LHemisf\%C3\%A8ric-Valencia_1-1024x692.jpg,

[31] http://www.archnewsnow.com/features/images/Feature0184_02x.jpg

[32] http://www.fastcompany.com/1514559/how-santiago-calatravas-buildings-marry-engineering-biology

[33] https://upload.wikimedia.org/wikipedia/hu/0/0e/Makovecz-Farkasr\%C3\%A9t.jpg

[34] http://varkapu.info/sites/default/files/pcsabaegyetem.jpg

[35] http://epiteszforum.hu/emlekezz-az-elokre-az-ujjaszuletes-kapolnaja-devecserben

[36] http://architizer.com/projects/boston-treepods/ 